\title{
Out of the bush: the Asian bush mosquito Aedes japonicus japonicus (Theobald, 1901) (Diptera, Culicidae) becomes invasive
}

\author{
Helge Kampen ${ }^{1 *}$ and Doreen Werner ${ }^{2}$
}

\begin{abstract}
The Asian bush or rock pool mosquito Aedes japonicus japonicus is one of the most expansive culicid species of the world. Being native to East Asia, this species was detected out of its original distribution range for the first time in the early 1990s in New Zealand where it could not establish, though. In 1998, established populations were reported from the eastern US, most likely as a result of introductions several years earlier. After a massive spread the mosquito is now widely distributed in eastern North America including Canada and two US states on the western coast. In the year 2000, it was demonstrated for the first time in Europe, continental France, but could be eliminated. A population that had appeared in Belgium in 2002 was not controlled until 2012 as it did not propagate. In 2008, immature developmental stages were discovered in a large area in northern Switzerland and bordering parts of Germany. Subsequent studies in Germany showed a wide distribution and several populations of the mosquito in various federal states. Also in 2011, the species was found in southeastern Austria (Styria) and neighbouring Slovenia. In 2013, a population was detected in the Central Netherlands, specimens were collected in southern Alsace, France, and the complete northeastern part of Slovenia was found colonized, with specimens also present across borders in adjacent Croatia. Apparently, at the end of 2013 a total of six populations occurred in Europe although it is not clear whether all of them are completely isolated. Similarly, it is not known whether these populations go back to the same number of introductions. While entry ports and long-distance continental migration routes are also obscure, it is likely that the international used tyre trade is the most important mode of intercontinental transportation of the mosquito. Aedes $j$. japonicus does not only display an aggressive biting behaviour but is suspected to be a vector of various disease agents and to displace indigenous culicid species. Therefore, Aedes j. japonicus might both cause public health problems in the future and have a significant impact on the biodiversity of the invaded territories.
\end{abstract}

Keywords: Aedes japonicus japonicus, Asian bush mosquito, Asian rock pool mosquito, Europe, International spread, Invasive species, North America, Vector potential

\section{Introduction}

Among vector arthropods invading (i.e. arriving, establishing and spreading in) new territories, mosquitoes have historically been especially successful [1]. A highly ranked listed invasive culicid species [2] is the Asian bush mosquito or Asian rock pool mosquito Aedes (Finlaya) japonicus japonicus (Theobald, 1901). It originates from East

\footnotetext{
* Correspondence: helge.kampen@fli.bund.de

${ }^{1}$ Friedrich-Loeffler-Institut, Federal Research Institute for Animal Health,

Südufer 10, Greifswald - Insel Riems 17493, Germany

Full list of author information is available at the end of the article
}

Asia and the Far East, where it represents one of four subspecies of Ae. japonicus. Similar to Aedes albopictus, it is transported to overseas territories mainly by the used tyre trade. Up to now, it has been discovered in Oceania (New Zealand), where it could not establish thanks to thorough inspection activities and early detection, as well as in North America and Europe, with the first detections outside its native distribution area dating back to the early 1990s (Table 1). We here summarize key data on the international spread, the biology and the harmful potential of Ae. j. japonicus.

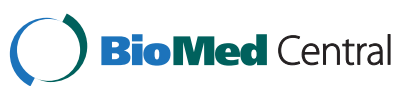

(c) 2014 Kampen and Werner; licensee BioMed Central Ltd. This is an Open Access article distributed under the terms of the Creative Commons Attribution License (http://creativecommons.org/licenses/by/2.0), which permits unrestricted use, distribution, and reproduction in any medium, provided the original work is properly cited. The Creative Commons Public Domain Dedication waiver (http://creativecommons.org/publicdomain/zero/1.0/) applies to the data made available in this article, unless otherwise stated. 
Table 1 Dates of first detection of invasion/establishment by Ae. j. japonicus

\begin{tabular}{|c|c|c|c|}
\hline $\begin{array}{l}\text { Year of first } \\
\text { detection }\end{array}$ & Country/state & Established & Reference \\
\hline \multirow[t]{2}{*}{1993} & New Zealand & & [3] \\
\hline & United States & - & \\
\hline 1998 & New Jersey & + & [4] \\
\hline 1998 & New York & + & [4] \\
\hline 1998 & Connecticut & + & {$[5]$} \\
\hline 1999 & Pennsylvania & + & [6] \\
\hline 1999 & Ohio & + & {$[7]$} \\
\hline 1999 & Rhode Island & + & {$[8]^{*}$} \\
\hline 2000 & New Hampshire & + & [9] \\
\hline 2000 & Massachusetts & + & [10] \\
\hline 2000 & Maryland & + & [11] \\
\hline 2000 & Virginia & + & [12] \\
\hline 2001 & Delaware & + & {$[8]^{*}$} \\
\hline 2001 & Maine & + & [13] \\
\hline 2001 & Vermont & + & [14] \\
\hline 2001 & Washington & + & [15] \\
\hline 2002 & Georgia & + & {$[16,17]$} \\
\hline 2002 & South Carolina & + & {$[16]$} \\
\hline 2002 & West Virginia & + & [18] \\
\hline 2003 & North Carolina & + & {$[17]$} \\
\hline 2003 & Tennessee & + & [19] \\
\hline 2003 & Kentucky & + & [20] \\
\hline 2003 & Hawaii & + & [21] \\
\hline 2003 & Michigan & + & [22] \\
\hline 2004 & Alabama & + & [23] \\
\hline 2004 & Wisconsin & + & [24] \\
\hline 2004 & Indiana & + & {$[25]$} \\
\hline 2005 & Missouri & + & {$[26]$} \\
\hline 2006 & Illinois & + & {$[27]$} \\
\hline 2006 & Oregon & + & {$[28]$} \\
\hline 2007 & Minnesota & + & [29] \\
\hline 2007 & lowa & + & {$[30]$} \\
\hline 2009 & South Dakota & + & [31] \\
\hline 2010 & Arkansas & + & {$[32]$} \\
\hline \multirow[t]{2}{*}{2011} & Mississippi & + & [33] \\
\hline & Canada & & \\
\hline 2001 & Quebec & + & {$[34]$} \\
\hline \multirow[t]{2}{*}{2001} & Ontario & + & {$[35]$} \\
\hline & Europe & & \\
\hline 2000 & France & - & {$[36]$} \\
\hline 2002 & Belgium & + & {$[37]$} \\
\hline 2008 & Switzerland & + & {$[38]$} \\
\hline 2008 & Germany & + & {$[38]$} \\
\hline
\end{tabular}

Table 1 Dates of first detection of invasion/establishment by Ae. j. japonicus (Continued)

\begin{tabular}{cccc}
\hline 2011 & Austria & + & {$[39]$} \\
2011 & Slovenia & + & {$[39]$} \\
2013 & Netherlands & + & {$[40]$} \\
2013 & Croatia & + & Merdić, pers. comm. \\
2013 & France & + & Schaffner, pers. comm. \\
*No original literature identifiable. & &
\end{tabular}

\section{Review}

Systematics of the Japonicus Group

Aedes japonicus occurs with four morphologically very similar subspecies: Ae. j. japonicus (Theobald, 1901), Ae. $j$. shintienensis Tsai \& Lien, 1950, Ae. j. amamiensis Tanaka, Mizusawa \& Saugstad, 1979, and Ae. j. yaeyamensis Tanaka, Mizusawa \& Saugstad, 1979. These varieties may be differentiated by the presence/absence and the particular design of a sub-basal dark band on their hind femora. Secondary characteristics are the colour, alignment and shape of the scales on their posterior pronotal lobes, on their subspiracular areas, on their costae and on their fourth hind tarsomeres [41]. The four subspecies are genetically distinct and form a monophyletic group together with Aedes koreicus [42].

\section{Distribution and spread}

The Ae. japonicus subspecies have characteristic distribution areas in Asia. Aedes j. japonicus is most wide-spread and has been recorded from Palaearctic Japan (Hokkaido, Honshu, Shikoku, Kyushu, Yakushima, Tsushima), the Ryukyu Archipelago, Korea (including both the Korean peninsula and Cheju Island), southern China including Hong Kong, Taiwan and southeastern Siberia (Primorskiy Kray). Aedes $j$. shintienensis is more restricted to the Oriental region, including Taiwan and Korea, while Ae. $j$. amamiensis occurs on Amami Guntô and Ae. j. yaeyamensis on Yaeyama Guntô, Okinawa Guntô and associated islands of the Ryukyu Archipelago [41,43,44].

For reasons not quite understood, only Ae. j. japonicus has become invasive. In principal, it is supposed to use the same transportation mechanisms as Ae. albopictus, primarily the second-hand tyre trade for intercontinental/long-distance overseas movement of the desiccationresistant eggs [45] and land-based trade and vehicle transport for the dispersal of eggs, larvae and adults on the ground $[6,46]$. Of course, land-based transport is also possible through displacement of tyres, and it is hypothesized that initial introductions into Ohio and Illinois could be attributed to interstate used tyre commerce $[7,27]$. It is assumed, however, that a major mode of spread across the USA might be connected to landbased vehicle transport and transit of adult mosquitoes 
via the Standardbred horse trade [6,47]. Furthermore, Gray et al. [17] and Bevins [48], who found Ae. j. japonicus larvae in rock pools associated with all major rivers in the Appalachians and Blue Ridge Mountains of the USA, discuss the possibility of active expansion along river corridors.

For Ae. albopictus, introduction of larvae through the lucky bamboo (Dracaena spec.) and machinery water and of adults on airplanes has been identified in addition to the used tyre pathway $[49,50]$. Similarly, Ae. j. japonicus was found in used machinery and water tankers arriving in New Zealand [51].

Aedes j. japonicus was first detected outside its native distribution range in New Zealand in 1993 [3]. Up to 2003, eight additional introductions were reported but all of them remained interceptions [51]. To date, no establishment of the species in New Zealand has become public.

In the US, three states notified collections of Ae. $j$. japonicus in 1998, New Jersey, New York and Connecticut $[4,5]$. Retrospectively, it is not clear when introduction had taken place but it is assumed that it must have been after 1992 since no Ae. j. japonicus specimens had been encountered during a previous intense monitoring programme for Ae. albopictus [52]. By 2011, Ae. j. japonicus was demonstrated in 33 US states including Hawaii (Figure 1, Table 1).

Early phylogenetic investigations by Fonseca et al. [6] on mosquitoes from the eastern US states suggest that there had been at least two independent introductions, since samples from New York, New Jersey and Connecticut represented genetic signatures significantly different from samples from Pennsylvania and Maryland. A more detailed study on mosquitoes collected up to 2005 provided evidence for continuous merging of the initial populations, thus producing increased genetic diversity [53].

While the spread of Ae. j. japonicus continued on the eastern US coast and gradually included more central states, establishment of the species was reported from Washington State on the western coast as early as in 2001 [15]. It remained unclear whether this was a result from movement of contaminated products (e.g. tyres) from the eastern states or from another intercontinental introduction event. In 2006, Oregon was the second western state to report occurrence of Ae. j. japonicus [28].

In 2001, the northeastern distribution area expanded towards Canada (Figure 1), and the rock pool mosquito was subsequently demonstrated in southern Quebec and southern Ontario [34,35].

In Europe, Aedes j. japonicus was first detected in 2000 in the form of two larvae in a storage yard of recycled tyres in a town in northwestern France [36]. According to Schaffner et al. [38], this introduction could be eliminated. In 2002, a used tyre-trading company in Central Belgium was found infested by $A e$. $j$. japonicus, and in 2008 the species was discovered on the premises of another Belgian company involved in the

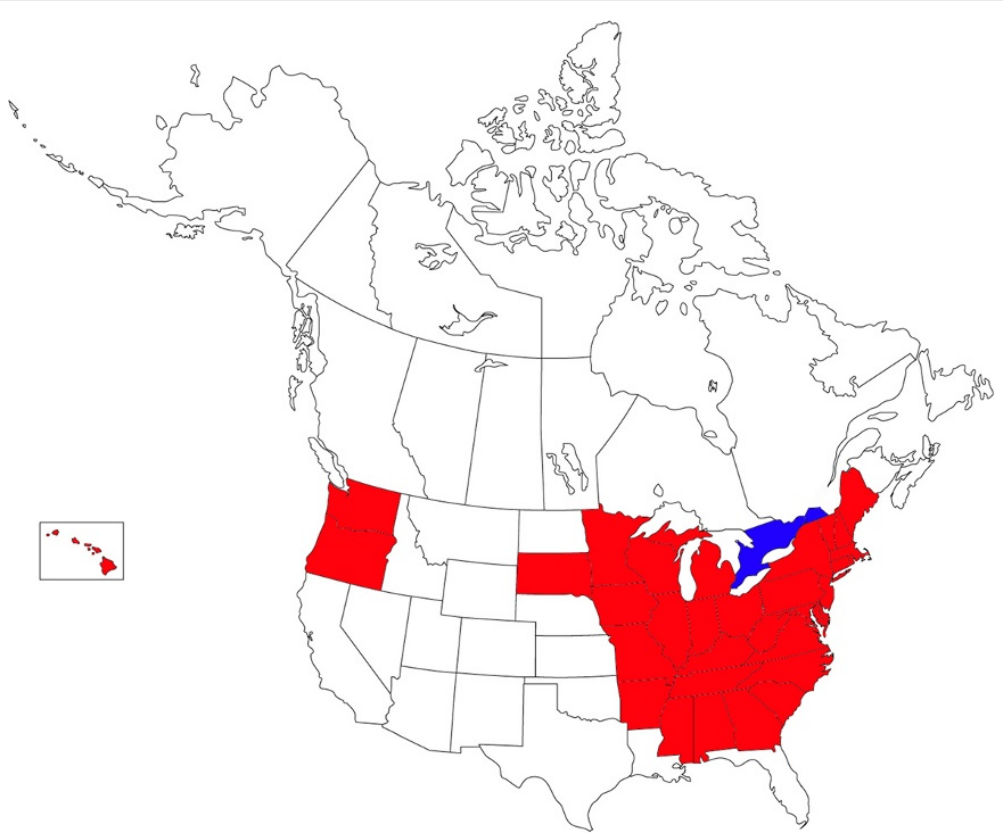

Figure 1 US states, including Hawaii (box), and Canadian provinces where Ae. j. japonicus was reported up to 2011 (red and blue colours, resp.) (US states are completely coloured in cases of mosquito detection, Ontario and Quebec provinces in Canada, due to their enormous size, only in those parts where Ae. j. japonicus was detected). 
second-hand tyre business in the same area [37]. From 2003 onwards, the bush mosquito was regularly collected in Belgium suggesting the establishment of a local population. Interestingly, a spatial spread beyond the companies' properties was observed only exceptionally although natural breeding sites were accepted in addition to discarded tyres [37]. Control efforts were only initiated in 2012 and continued in 2013, but final eradication could not be confirmed so far (Schaffner, pers. comm.).

Schaffner et al. [38] reported the presence of another European distribution area of Ae. j. japonicus in 2008 from northern Switzerland, spreading crossborder into Germany. Prompted by this finding, a monitoring programme carried out in southern Germany demonstrated a wide-spread population in 2009 with further expansion up to 2012 [54-56], (Becker, pers. comm.). Additional populations were found in 2012 in western Germany [57] and in 2013 in northern Germany [58] after individual mosquitoes were submitted to the authors for identification by private persons. Since the West German area was considerably larger and more densely populated than the North German one, it was assumed to be older. Most of the positive sites in northern Germany were located close to a motorway connecting the two distribution areas, suggesting that the North German population was probably an offshoot of the West German one [58].
Apparently, the Swiss/South German population expands westwards as Ae. j. japonicus specimens were detected in southern Alsace in 2013 (Schaffner, pers. comm.).

In 2011, immature bush mosquito stages were also collected in the border region of Austria (Styria) and Slovenia [39]. During a monitoring in Slovenia carried out in 2013, the whole north-eastern half of Slovenia was found colonized by Ae. j. japonicus [59], with frontier crossing to Croatia where several specimens were detected in 2013 close to the Slovenian border (Merdić, pers. comm.).

A single Ae. j. japonicus specimen was trapped in the Central Netherlands during routine monitoring in 2012, prompting a more thorough surveillance in the affected municipality with a closer trap grid in 2013. When several females were found, a site inspection produced numerous breeding sites containing preimaginal stages [40].

In summary, it appears that six spatially separated colonization areas exist in Europe: Belgium (being treated), northern Switzerland/France/southern Germany, western Germany, northern Germany, Austria/Slovenia/ Croatia and the Central Netherlands (Figure 2). Except for Belgium, it is not known where the mosquitoes came from and how they were imported [e.g. 38,57]. It is also not clear whether the various European populations are related to each other and whether they go back to different

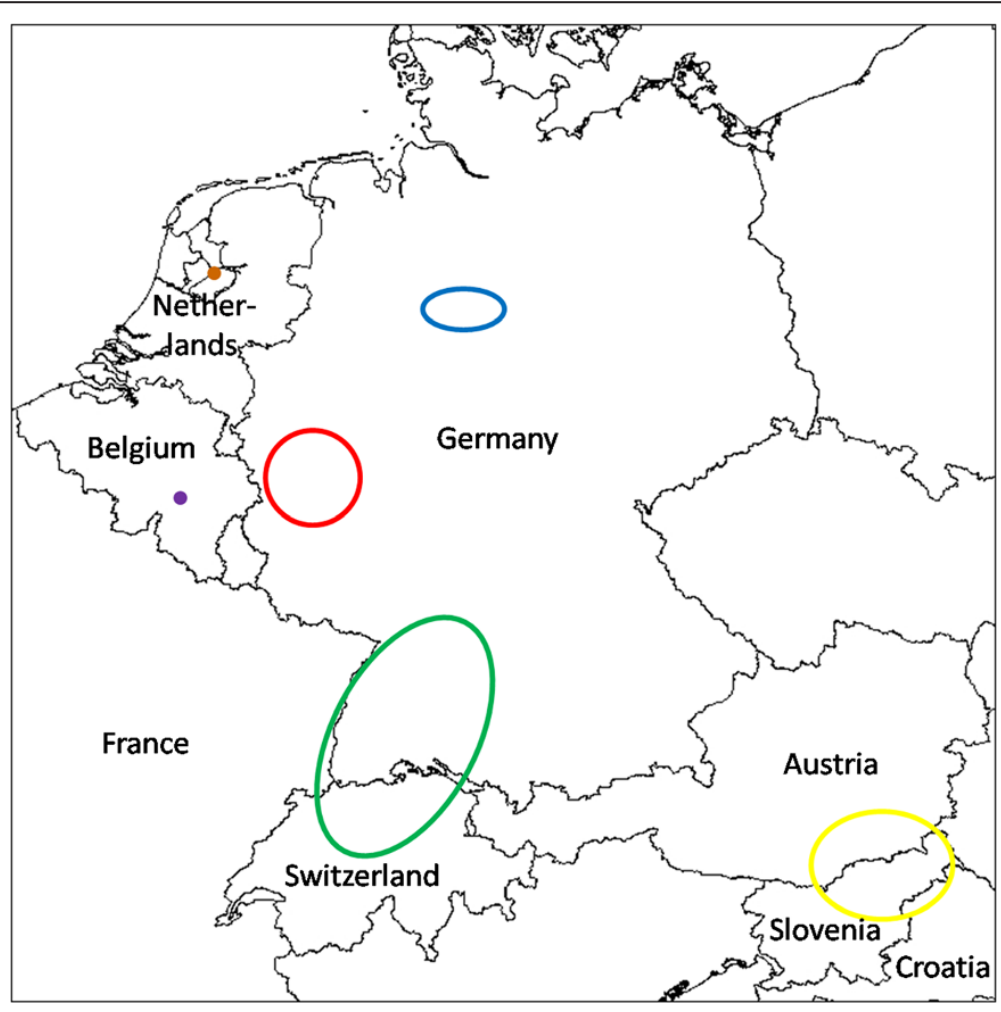

Figure 2 European distribution areas of Ae. j. japonicus as of late 2013. 
introduction events. Population genetic analyses using microsatellite signatures are underway to shed light on their relationships and geographic origins.

\section{Biology}

Aedes j. japonicus is a mosquito species adapted to temperate climates, capable of withstanding cold and snowy winters as occuring in its endemic home range in northern Japan. According to Kamimura [60], overwintering takes place as eggs in northeastern Japan and as larvae in southwestern Japan. In the southern Appalachians, USA, larvae were found at altitudes of up to $1,500 \mathrm{~m}$ where winter temperatures can reach $-18^{\circ} \mathrm{C}$ [48].

The life-cycle is multivoltine both in Japan [61] and in the eastern US [52]. During a five-year period in southern New Hampshire, Burger \& Davis [9] observed hatching of larvae at the end of March, as soon as breeding sites lost their ice cover, at water temperatures of 4.0$4.5^{\circ} \mathrm{C}$. Larvae were present until freezing produced a new ice cover in late October or early November. In laboratory studies larvae were demonstrated to hatch at $5^{\circ} \mathrm{C}$ water temperature and to be able to survive extended periods at low temperatures (e.g. 141 days at $\left.10^{\circ} \mathrm{C}[8]\right)$. These observations suggest that Ae. j. japonicus can indeed overwinter in the larval stage as communicated by Kamimura [60] for southern Japan.

The activity period of adults may last from May to October [62,63] or, at mild temperatures, even to early December [64]. At $22^{\circ} \mathrm{C}$ under laboratory conditions, preimaginal development, i.e. the period from larval hatching to adult emergence, takes two to four weeks [8]. Females exhibit a crepuscular/diurnal biting habit $[65,66]$ and are assumed to have a relatively short flight range [6].

Aedes j. japonicus has a preference for forested and bushy areas, be they in agricultural, rural, suburban or urban settings [41,52]. Being essentially a rock-hole breeder in its native range [41], streamside rock pools are among numerous other natural and movable or stationary artificial containers colonized elsewhere. Larvae can be found in tree-holes, leaf axils, tree stumps, rain water pools, ditches, subterranean catch basins, used tyre casings, stone vessels, drainage pipes, drinking fountains, tin cans, bath tubs, bird baths, roof gutters, flower vases, water dishes for pot plants, plastic cartons, vinyl tarpaulins, street gutters, rain water barrels, buckets, pans, etc. $[16,38,48,52,62,67-72]$. Strikingly, the breeding habitats often contain decaying leaves, twigs, other decomposing organic matter and algae [41,52,62]. Larval collections in extremely dirty artificial containers, such as used ashtrays, indicate a high tolerance to environmental pollutants [35].

Breeding sites are selected in both sun-lit and shaded environments [41,52], suggesting that the larvae and pupae can tolerate a wide range of water temperatures [71]. However, confirming the mosquito's distribution boundaries in Japan [41], the frequent lack of Ae. j. japonicus in warm water pools fully exposed to the sun in some areas led Andreadis \& Wolfe [73] to suggest that a temperature barrier may exist for this species preventing the colonization of regions with relatively high summer temperatures. This may explain the present, more northerly distribution areas in Europe and North America. In the southern US state Alabama, for example, a single $A e$. j. japonicus female was trapped in the northeasternmost corner in 2005, whereas no specimens at all were encountered in any other county during a state-wide survey of tyre-breeding mosquitoes [74]. Also in Europe, establishment has as yet been demonstrated only in the central countries where a temperate climate prevails, but not in southern subtropical regions.

In Japan, Ae. j. japonicus females are said to be reluctant to bite humans [41,62], whereas they readily feed on chicken and mice in the laboratory, but not on reptiles or amphibians [75]. Williges et al. [76] feed their laboratory colony on guinea pigs, and Takashima \& Rosen [77], Sardelis \& Turell [11] and Sardelis et al. [78-80] used chickens, hamsters and mice, respectively, as blood hosts for transmission studies. In contrast to extensive biting study observations in the field by LaCasse \& Yamaguti [62] where Ae. j. japonicus was never encountered, Iriarte et al. [61] reported Ae. j. japonicus to be abundant near human dwellings in urban areas, and Kamimura [81] and Andreadis et al. [52] actually observed attraction to, and even attacks on, humans in the field, indicating a feeding purpose. Knight [67] also argues that the species will readily bite humans entering their habitats. While analyzing blood meals from wildcaught Ae. j. japonicus, Apperson et al. [82] found that all tested samples were of mammalian but none of human origin. Molaei et al. [83], however, demonstrated acquisition of blood from human hosts in a third of examined blood-engorged females. In summary, there is evidence that the bush mosquito feeds on both avian and mammalian, including human, hosts. Vector competence provided, this indiscriminant behaviour makes it a potential bridge vector of zoonotic viruses such as West Nile virus (WNV).

Once established under adequate climatic conditions, Aedes $j$. japonicus may quickly propagate. In some newly infested areas, the invader was detected quite early, either by chance or as a consequence of routine mosquito surveillance, when population densities were still low and distribution was limited. It has commonly been observed that detection frequency, together with breeding site numbers and spatial distribution, will usually increase significantly within one to three years after the initial phase of colonization, resulting from considerable 
population growth $[9,20,22,27,35]$. However, the initial phase of colonization is missed in some areas, and the mosquito's presence is only recognized with some delay, probably a few years, when high population numbers and a wide-spread distribution have already been reached [e.g. 5,11,52].

Along with the observed adaptive capacity and successful proliferation of Ae. j. japonicus in many areas of North America and Europe comes evidence that it represses the population densities of other culicids $[9,57,73,84]$. Such a displacement of indigenous mosquito species would of course directly affect the biodiversity and may also have direct or indirect effects on the epidemiology of mosquito-borne diseases [48,85]. While competitive advantage could not be proven so far or remains anecdotal in Europe [38,57], there is evidence from the US that Ae. j. japonicus larvae outcompete larvae of other species. A decline in relative abundances as compared to Ae. j. japonicus has been reported for Aedes atropalpus, Aedes triseriatus, Culex restuans and even Culex pipiens [22,72,73,84-86]. Handicaps of Ae. atropalpus, for example, are hypothesized to be autogeny and a longer larval development [85]. Aedes triseriatus is inferior in sunlit peridomestic locations [72] and Cx. pipiens when decaying leaves and algae are the only food sources [86]. Similar negative effects with weak support for Ae. j. japonicus over Ae. triseriatus with regard to development time were also observed by Alto [87] when these two species were co-bred under artificial conditions. These observations contrast somewhat with studies which indicate that $C x$. pipiens maintained similar larval populations in tyres before and after the introduction of Ae.j. japonicus in Connecticut [73] and with studies of larval competition between Ae. j. japonicus and $C x$. pipiens reared on laboratory diets which indicate that the two species are equivalent competitors [88].

Being possibly superior in competition to a number of native culicid species, Ae. j. japonicus larvae have been shown in laboratory experiments to be inferior to the Asian tiger mosquito Ae. albopictus [89], another invasive container-breeding culicid species which had started its worldwide spread long before the Asian bush mosquito [90-92]. This would be unfortunate if transferable to natural conditions since Ae. albopictus is a highly efficient vector of dirofilarial nematodes and more than 20 arboviruses including many of public health relevance [93]. It is therefore thought to pose a considerably greater threat to invaded countries than Ae. j. japonicus. Field observations made by Bartlett-Healy et al. [94] do not necessarily support the laboratory results of Armistead et al. [89]. They rather suggest that species abundance depends on urban, suburban or rural surroundings, with Ae. albopictus being more abundant in urban and suburban settings, and Ae. $j$. japonicus being more abundant in rural settings when both are sympatric.

There are most likely numerous factors to be considered simultaneously when larval competition is to be determined, such as food resource availability and quality, water quality, shade and insolation, and temperature [94]. Thus, the competition between Ae. j. japonicus and Aedes epactius, another US resident mosquito species, appears to be clearly dependent on season-associated temperature [32]. Early in the year, when temperatures are cooler, Ae. j. japonicus is the dominating species in rock hole habitats while later in the year, during the hotter months, Ae. epactius is more frequent.

\section{Vector potential}

Aedes j. japonicus is not considered an important vector in its native Asian distribution area, and evidence for a major role in field transmission of disease agents is generally absent. Some data suggesting a vector potential for several viruses of medical and veterinary relevance, however, exist both from the field and from laboratory infection and transmission studies (Table 2). While Russian and Japanese researchers were interested in the susceptibility of Ae. j. japonicus to Japanese encephalitis virus (JEV), which is endemic in many East Asian countries where the mosquito occurs, long before the discovery of the mosquito becoming invasive, western colleagues have

Table 2 Demonstrated role of Ae. j. japonicus in pathogen transmission

\begin{tabular}{|c|c|c|c|c|c|}
\hline & Field transmission & Field infection & Laboratory transmission & Laboratory infection & Reference \\
\hline West Nile virus & $?$ & + & + & + & {$[11,95-97]$} \\
\hline Japanese encephalitis virus & $?$ & + & + & + & {$[77,98-100]$} \\
\hline St. Louis encephalitis virus & $?$ & & + & + & {$[80]$} \\
\hline Eastern equine encephalitis virus & $?$ & & + & + & [78] \\
\hline La Crosse virus & $?$ & & + & + & [79] \\
\hline Rift Valley fever virus & $?$ & & + & + & [101] \\
\hline Chikungunya virus & $?$ & & & + & [102] \\
\hline Dengue virus & $?$ & & & + & [102] \\
\hline Getah virus & $?$ & & & + & [103] \\
\hline
\end{tabular}


mainly addressed the question of vector competence only after the emergence of the bush mosquito on other continents (Table 2).

Thus, Mitamura et al. [98] reported experimental JEV infection and subsequent transmission by Ae. j. japonicus in Japan decades ago, whereas the mosquitoes became infected but did not transmit the virus in a Russian study by Petrischeva \& Shubladse [99]. Specimens positive for JEV were also found in the field in Russia [100]. Takashima \& Rosen [77] have later shown the capability of Ae. j. japonicus of transmitting the virus both horizontally and vertically in the laboratory. In the field, its vector role for JEV may be obscured by the principal vector, Culex tritaeniorhynchus, which breeds in the countless Asian rice fields. Aedes j. japonicus probably may only gain some significance as a vector in areas devoid of rice fields and Cx. tritaeniorhynchus [104]. JEV causes serious encephalitides in humans and horses and abortion in pigs [105].

Turell et al. [95,96] and Sardelis \& Turell [11] have shown laboratory transmission of WNV by feeding Ae. $j$. japonicus on viremic chickens and re-feeding them on naïve chickens after a period of two weeks. WNV affects birds, equines and humans, where infections may go asymptomatically or cause encephalitis, meningitis, flaccid paralysis and even death. Epidemics have occurred in Europe, Africa, North and Central America, the Middle East and parts of Asia [106]. Major WNV vectors are Culex species but the virus was found in numerous field-collected pools of Ae. j. japonicus from at least nine different US states between 2000 and 2009 [83,97].

Sardelis et al. [78-80] also described experimental transmission of eastern equine encephalitis virus (EEEV), La Crosse virus (LACV) and St. Louis encephalitis virus (SLEV) by Ae. j. japonicus fed on viremic chickens or hamsters first and on naïve chickens or suckling mice one to three weeks later, respectively. Most human infections with all three viruses remain subclinical or inapparent, while in some cases they may involve the central nervous system and cause severe encephalitides and death. LACV and EEEV are restricted to North America where the principal mosquito vectors are Culiseta melanura and Ae. triseriatus, respectively [107,108]. SLEV is distributed throughout the Americas and is transmitted by various Culex species [109].

Quite recently, Turell et al. [101] also demonstrated efficient laboratory transmission of Rift Valley fever virus (RVFV) by Ae. j. japonicus. More than $90 \%$ of all mosquitoes fed on viremic hamsters had disseminated infections from seven days post infection onwards, and virus transmission to susceptible hamsters readily occurred. RVFV virus is highly pathogenic to humans and ruminants $[110,111]$ and raises great concern that it might be imported into Europe and North America [112,113]. It has long been endemic to sub-Saharan Africa but epidemics have increasingly been occurring in North Africa and the Middle East [112]. Notably, RVFV is also transmitted transovarially by some mosquito species. Infected females pass the virus over to the next generation via the eggs resulting in the fact that the virus can persist in the mosquito population over extended periods of time without involvement of a vertebrate host [114].

Susceptibility to infection, but not virus transmission, has been shown for chikungunya and dengue viruses by Schaffner et al. [102], by artificial feeding of Ae. j. japonicus on viremic blood through chicken skin and saliva titration 14 days later. Occurrence of the viral particles in the saliva indicated vector competence. Both viruses have been proven to be transmitted by synanthropic $A e$ des species, such as Ae. albopictus and Aedes aegypti, and have recently caused large unexpected outbreaks in northern Italy (chikungunya [115]) and on the Portuguese island of Madeira (dengue [116]), respectively. Chikungunya may be associated with long-lasting and painful polyarthralgia [117] while dengue may present with a hemorrhagic fever or a shock syndrome and be fatal [118].

Getah virus occurs in southeastern Asia and Australia, is transmitted by various Aedes and Culex species, and has been described as causing disease in horses, characterized by pyrexia, urticaria, rash and oedema of the hind legs [119]. Aedes j. japonicus showed susceptible to the virus when fed on viremic blood through pig skin membrane as demonstrated by titration of whole mosquito homogenates 21 days after blood ingestion [103].

\section{Conclusion}

Although being capable of transmitting pathogenic viruses in the laboratory, Aedes $j$. japonicus has not been confirmed to be a vector of disease agents in the field. Whether there are intrinsic factors generally preventing the species from becoming a conspicuous and efficient vector or whether the non-appearance to date of $A e . j$. japonicus as a vector is by chance, due to the mosquito and dangerous pathogens not being endemic in the same regions, remains to be elucidated.

Aedes $j$. japonicus seems to be highly adaptive and to have competitive advantages over some mosquito species indigenous to the invaded regions. In the long-term, this may not only have direct effects on the biodiversity by a change of the mosquito fauna but may also have indirect impacts on the epidemiology of mosquito-borne diseases should they occur in the infested regions.

In many cases, in particular in Europe, the origin, the port(s) of entry and the modes of continental transportation of Ae. j. japonicus are unknown. More ecological, population genetic and vector competence studies are fundamental to a better understanding of the establishment 
and spread of Ae. j. japonicus and an assessment of its impact on public health. In this context, biological and ecological data at the natural range of distribution in Asia and overseas regions where the species has become established (North America and Europe) could be used to develop predictive distribution maps for countries where it has not been already introduced.

Given the wide distribution of established populations, both in North America and Europe, it is wishful thinking that Ae. j. japonicus can again be eradicated. Instead, it is imperative to accept it as having become a part of the indigenous mosquito fauna and to try to keep its population densities at a possible minimum by educating and training community workers, personnel involved in gardening and landscaping etc., as well as the general public as to how to avoid producing potential breeding sites.

\section{Abbreviations}

CDC: Centers for Disease Control and Prevention; EEEC: Eastern equine encephalitis virus; JEV: Japanese encephalitis virus; LACV: La Crosse virus; RVFV: Rift Valley fever virus; SLEV: St. Louis encephalitis virus; WNV: West Nile virus.

\section{Competing interests}

The authors declare that they have no competing interests.

\section{Authors' contributions}

Both authors contributed equally to the literature research and writing of the manuscript. Both authors read and approved the final manuscript.

\section{Acknowledgement}

We are grateful to Adrian Pont (Oxford University Museum for Natural History, UK) for critically reading the manuscript.

\section{Author details}

${ }^{1}$ Friedrich-Loeffler-Institut, Federal Research Institute for Animal Health, Südufer 10, Greifswald - Insel Riems 17493, Germany. ${ }^{2}$ Leibniz Centre for Agricultural Landscape Research, Eberswalder Str. 84, Müncheberg 15374, Germany.

Received: 30 October 2013 Accepted: 24 January 2014

Published: 4 February 2014

\section{References}

1. Lounibos LP: Invasions by insect vectors of human disease. Annu Rev Entomol 2002, 47:233-266.

2. GISD (Global Invasive Species Database): http://www.issg.org/database/ welcome.

3. Laird M, Calder L, Thornton RC, Syme R, Holder PW, Mogi M: Japanese Aedes albopictus among four mosquito species reaching New Zealand in used tires. J Am Mosa Control Assoc 1994, 10:14-23.

4. Peyton EL, Campbell SR, Candeletti TM, Romanowski M, Crans WJ: Aedes (Finlaya) japonicus japonicus (Theobald), a new introduction into the United States. J Am Mosq Control Assoc 1999, 15:238-241.

5. Munstermann LE, Andreadis TG: Aedes japonicus in Connecticut. Vector Ecol News/ 1999, 30:7-8.

6. Fonseca DM, Campbell S, Crans WJ, Mogi M, Miyagi I, Toma T, Bullians M, Andreadis TG, Berry RL, Pagac B, Sardelis MR, Wilkerson RC: Aedes (Finlaya) japonicus (Diptera: Culicidae), a newly recognized mosquito in the United States: analyses of genetic variation in the United States and putative source populations. J Med Entomol 2001, 38:135-146.

7. ProMED: Aedes japonicus - USA (Ohio). Archive no. 19991022.1897. 1999. http://www.promedmail.org.

8. Scott JJ: The Ecology of the Exotic Mosquito Ochlerotatus (Finlaya) japonicus japonicus (Theobald 1901) (Diptera: Culicidae) and an Examination of its Role in the West Nile Virus Cycle in New Jersey. New Brunswick, NJ: Ph.D. thesis, Rutgers University; 2003.
9. Burger JF, Davis H: Discovery of Ochlerotatus japonicus japonicus (Theobald) (Diptera: Culicidae) in southern New Hampshire, USA and its subsequent increase in abundance in used tire casings. Entomol News 2008, 119:439-444.

10. Central Massachusetts Mosquito Control Project: Discovery of new mosquito species in Massachusetts. 2000. http://www.cmmcp.org/japonicus.pdf.

11. Sardelis MR, Turell MJ: Ochlerotatus j. japonicus in Frederick County, Maryland: discovery, distribution, and vector competence for West Nile virus. J Am Mosq Control Assoc 2001, 17:137-141.

12. Harrison BA, Whitt PB, Cope SE, Payne GR, Rankin SE, Bohn LJ, Stell FM, Neely CJ: Mosquitoes (Diptera: Culicidae) collected near the Great Dismal Swamp: new state records, notes on certain species and a revised checklist for Virginia. Proc Entomol Soc Wash 2002, 104:655-662.

13. Foss KA, Dearborn RG: Preliminary faunistic survey of mosquito species (Diptera: Culicidae) with a focus on population densities and potential breeding sites in Greater Portland, Maine. Maine Department of Conservation 2001, 42:36. Technical Report

14. Graham AC, Turmel J: Distribution Records of Vermont's First Introduced Mosquito Species, Ochlerotatus japonicus (Diptera, Culicidae). Salem, MA: Northeastern Mosquito Control Association, 47th Annual Meeting; 2001. Proceedings:121.

15. Roppo MR, Lilja JL, Maloney FA, Sames WJ: First occurrence of Ochlerotatus japonicus in the state of Washington. J Am Mosa Control Assoc 2004, 20:83-84.

16. Reeves WK, Korecki JA: Ochlerotatus japonicus japonicus (Theobald) (Diptera: Culicidae), a new invasive mosquito for Georgia and South Carolina. Proc Entomol Soc Wash 2004, 106:233-234.

17. Gray EW, Harrison BA, Womack ML, Kerce J, Neely CJ, Noblet R: Ochlerotatus japonicus japonicus (Theobald) in Georgia and North Carolina. J Am Mosq Control Assoc 2005, 21:144-146.

18. Joy JE: Larval mosquitoes in abandoned tire pile sites from West Virginia. J Am Mosa Control Assoc 2004, 20:12-17.

19. Caldwell ND, Gerhardt RR, Jones CJ: First collection of Ochlerotatus japonicus japonicus in the state of Tennessee. J Am Mosq Control Assoc 2005, 21:322-324.

20. Saenz VL, Townsend LH, Vanderpool RM, Schardein MJ, Trout RT, Brown GC: Ochlerotatus japonicus japonicus in the state of Kentucky. J Am Mosq Control Assoc 2006, 22:754-755.

21. Larish LB, Savage HM: Introduction and establishment of Aedes (Finlaya) japonicus japonicus (Theobald) on the island of Hawaii: implications for arbovirus transmission. J Am Mosq Control Assoc 2005, 21:318-321.

22. Kaufman MG, Stanuszek WW, Brouhard EA, Knepper RG, Walker ED: Establishment of Aedes japonicus japonicus and its colonization of container habitats in Michigan. J Med Entomol 2012, 49:1307-1317.

23. Mullen GR: First report of Ochlerotatus japonicus in Alabama. Alab Vector Manage Soc News/ 2005, 15:2.

24. Hughes TH, Irwin PM, Kaufman A, Sage H, Pagac BB Jr, Paskewitz SM: First records of Aedes japonicus japonicus in Wisconsin. J Am Mosa Control Assoc 2008, 24:583-584.

25. Young CLE, Beery JA, Sheffer RE, Rand KM: First record of Ochlerotatus japonicus (Diptera: Culicidae) in St. Joseph County, Indiana. Great Lakes Entomol 2004, 37:196-197.

26. Gallitano S, Blaustein L, Vonesh J: First occurrence of Ochlerotatus japonicus in Missouri. J Vector Ecol 2005, 30:347-348.

27. Morris JA, Lampman RL, Ballmes G, Funes J, Halvorsen J, Novak RJ: First record of Aedes japonicus japonicus in Illinois: defining its spatial distribution and associated mosquito species. J Am Mosq Control Assoc 2007, 23:243-251.

28. Wirth CM: Ochlerotatus japonicus found in Multnomah County. Vector News 2006, 35:4-5.

29. Neitzel DF, Johnson KA, Brogren S, Kemperman MM: First collection records of Aedes japonicus in Minnesota. J Am Mosq Control Assoc 2009, 25:367-369.

30. Dunphy BM, Tucker BJ, Petersen MJ, Blitvich BJ, Bartholomay LC: Arrival and establishment of Aedes japonicus japonicus (Diptera: Culicidae) in lowa. J Med Entomol 2009, 46:1282-1289.

31. ProMED: Mosquito, imported - USA (South Dakota). Archive no. 20091022.3640. 2009. http://www.promedmail.org.

32. Gaspar JP, McKay T, Huss MJ: First report of Aedes japonicus in natural and artificial habitats in northeastern Arkansas. J Am Mosq Control Assoc 2012, 28:38-42. 
33. Thorn M, Varnado WC, Goddard J: First record of Aedes japonicus japonicus in Mississippi. J Am Mosq Control Assoc 2012, 28:43-44.

34. Savignac R, Back C, Bourassa J: Biological Notes on Ochlerotatus japonicus and Other Mosquito Species New to Quebec. Denver, CO: Joint Meeting 68th Annual Meeting of the American Mosquito Control Association and the West Central Mosquito \& Vector Control Association; 2002. Abstracts:21-22.

35. Thielman A, Hunter FF: Establishment of Ochlerotatus japonicus (Diptera: Culicidae) in Ontario, Canada. J Med Entomol 2006, 43:138-142.

36. Schaffner F, Chouin S, Guilloteau J: First record of Ochlerotatus (Finlaya) japonicus japonicus (Theobald, 1901) in metropolitan France. J Am Mosa Control Assoc 2003, 19:1-5.

37. Versteirt V, Schaffner F, Garros C, Dekoninck W, Coosemans M, Van Bortel W: Introduction and establishment of the exotic mosquito species Aedes japonicus japonicus (Diptera: Culicidae) in Belgium. J Med Entomol 2009, 46:1464-1467.

38. Schaffner F, Kaufmann C, Hegglin D, Mathis A: The invasive mosquito Aedes japonicus in Central Europe. Med Vet Entomol 2009, 23:448-451.

39. Seidel B, Duh D, Novotny N, Allerberger F: Erstnachweis der Stechmücken Aedes (Ochlerotatus) japonicus (Theobald, 1901) in Österreich und Slowenien in 2001 und für Aedes (Stegomyia) albopictus (Skuse, 1895) in Österreich 2012 (Diptera: Culicidae). Entomol Z 2012, 122:223-226.

40. Ibáñez-Justicia A, Kampen H, Braks M, Schaffner F, Steeghs M, Werner D, Zielke D, den Hartog W, Brooks M, Dik M, van de Vossenberg B, Scholte E-J: First report of Aedes japonicus japonicus (Theobald, 1901) (Diptera, Culicidae) population in The Netherlands. J Eur Mosa Control Assoc 2014, 31.

41. Tanaka K, Mizusawa K, Saugstad ES: A revision of the adult and larval mosquitoes of Japan (including the Ryukyu Archipelago and the Ogasawara Islands) and Korea (Diptera: Culicidae). Contrib Amer Ent Inst 1979, 16:1-987.

42. Cameron EC, Wilkerson RC, Mogi M, Miyagi I, Toma T, Kim HC, Fonseca DM: Molecular phylogenetics of Aedes japonicus, a disease vector that recently invaded Western Europe, North America, and the Hawaiian islands. J Med Entomol 2010, 47:527-535.

43. Gutsevich AV, Dubitskiy AM: New Species of Mosquitoes in USSR fauna. Leningrad, Russia: Nauka; 1981 [In Russian].

44. Lu B, Li B, Ji S, Chen H, Meng Q, Suo L, Qu F, Gong Z, Zhang Z: Fauna Sinica, Insecta. Vol. 8, Diptera: Culicidae 1. Beijing, China: Science Press; 1997 [In Chinese].

45. Reiter $P$, Sprenger $D$ : The used tire trade: a mechanism for the worldwide dispersal of container breeding mosquitoes. J Am Mosq Control AssoC 1987, 3:494-501.

46. Kampen H, Kronefeld M, Zielke D, Werner D: Further specimens of the Asian tiger mosquito Aedes albopictus (Diptera, Culicidae) trapped in southwest Germany. Parasitol Res 2013, 112:905-907.

47. Scott JJ, MCNelly JR, Crans WJ: Aedes japonicus overwinters in New Jersey. Vector Ecol News/ 1999, 30:6-7.

48. Bevins SN: Establishment and abundance of a recently introduced mosquito species Ochlerotatus japonicus (Diptera: Culicidae) in the Southern Appalachians, USA. J Med Entomol 2007, 44:945-952.

49. Linthicum KJ, Kramer VL, Madon MB, Fujioka K, Surveillance-Control Team: Introduction and potential establishment of Aedes albopictus in California in 2001. J Am Mosa Contr Assoc 2003, 19:301-308.

50. Hofhuis A, Reimerink J, Reusken C, Scholte EJ, Boer A, Takken W, Koopmans $\mathrm{M}$ : The hidden passenger of lucky bamboo: do imported Aedes albopictus mosquitoes cause dengue virus transmission in the Netherlands? Vector-borne Zoon Dis 2009, 9:217-220.

51. Derraik JGB: Exotic mosquitoes in New Zealand: a review of species intercepted, their pathways and ports of entry. Aust N Z J Publ Health 2004, 28:433-444.

52. Andreadis TG, Anderson JF, Munstermann LE, Wolfe RJ, Florin DA: Discovery, distribution, and abundance of the newly introduced mosquito Ochlerotatus japonicus (Diptera: Culicidae) in Connecticut, USA. J Med Entomol 2001, 38:774-779.

53. Fonseca DM, Widdel AK, Hutchinson M, Spichiger SE, Kramer LD: Fine-scale spatial and temporal population genetics of Aedes japonicus, a new US mosquito, reveal multiple introductions. Mol Ecol 2010, 19:1559-1572.

54. Becker N, Huber K, Pluskota B, Kaiser A: Ochlerotatus japonicus japonicus a neozoon in Germany and a revised list of the German mosquito fauna. Eur Mosa Bull 2011, 9:88-102.

55. Schneider K: Breeding of Ochlerotatus japonicus japonicus (Diptera: Culicidae) $80 \mathrm{~km}$ north of its known range in southern Germany. Eur Mosq Bull 2011, 29:129-132.
56. Huber K, Pluskota B, Jöst A, Hoffmann K, Becker N: Status of the invasive species Aedes japonicus japonicus (Diptera: Culicidae) in southwest Germany in 2011. J Vector Ecol 2012, 37:462-465.

57. Kampen $\mathrm{H}$, Zielke D, Werner D: A new focus of Aedes japonicus japonicus (Theobald, 1901) (Diptera, Culicidae) distribution in western Germany: rapid spread or a further introduction event? Parasit Vectors 2012, 5:284.

58. Werner D, Kampen $\mathrm{H}$ : The further spread of Aedes japonicus japonicus (Diptera, Culicidae) towards northern Germany. Parasitol Res 2013, 112:3665-3668.

59. Kalan K, Kryštufek B: Surveillance of Invasive Mosquitoes in Slovenia, with Updates on the Distribution of Aedes japonicus. Antwerp, Belgium: Joint VBORNET-EMCA Meeting on 'Invasive Mosquitoes and Public Health in the European Context; 2013. Abstracts:11.

60. Kamimura K: On the Japanese species of the family Culicidae. In Science of Mosquitoes. Edited by Sasa M, Kurihara T, Kamimura K. Tokyo, Japan: Hokuryukan; 1976:150-188 [In Japanese]

61. Iriarte WLZ, Tsuda Y, Wada Y, Takagi M: Distribution of mosquitoes on a hill of Nagasaki City with emphasis to the distance from human dwellings. Trop Med 1991, 33:55-60.

62. LaCasse WJ, Yamaguti S: Mosquito Fauna of Japan and Korea, Part II. Japan: Corps of Engineers, US Army Headquarters I Corps, APO 301; 1948.

63. Falco RC, Daniels TJ, Slameck MC: Prevalence and distribution of Ochlerotatus japonicus (Diptera: Culicidae) in two counties in southern New York State. J Med Entomol 2002, 39:920-925.

64. Scott JJ, Crans WJ: Expanded polystyrene (EPS) floats for surveillance of Ochlerotatus japonicus. J Am Mosq Control Assoc 2004, 19:376-381.

65. Chiba Y: Species specificity in the circadian pattern of mosquitoes. Jpn $J$ Ecol 1971, 20:237-243

66. Kawada H, Tatsuta H, Arikawa K, Takagi M: Comparative study on the relationship between photoperiodic host-seeking behavioral patterns and the eye parameters of mosquitoes. J Insect Phys 2006, 52:67-75.

67. Knight KL: Contributions to the mosquito fauna of Southeast Asia. - IV: Species of the subgroup Chrysolineatus of group D, genus Aedes, subgenus Finlaya Theobald. Contrib Am Entomol Inst 1968, 2:1-45.

68. Sato S, Inada Y, Kaida K, Ose S, Nishitani H: The larval habitats of mosquitoes in the Oshima Prefecture Japan. J Hokkaido Univ Ed Sec I/ B 1981, 31:25-40.

69. Sota T, Mogi S, Hayamizu E: Habitat stability and the larval mosquito community in treeholes and other containers on a temperate island. Res Pop Ecol (Kyoto) 1994, 36:93-104.

70. Tsuda Y, Takagi M, Wada Y: Ecological study on mosquito communities in tree holes in Nagasaki, Japan, with special reference to Aedes albopictus. Jpn J Sanit Zool 1994, 45:103-111.

71. Oliver J, Means RG, Howard JJ: Geographic distribution of Ochlerotatus japonicus in New York State. J Am Mosq Control Assoc 2003, 19:121-124.

72. Joy JE, Sullivan SN: Occurrence of tire inhabiting mosquito larvae in different geographic regions of West Virginia. J Am Mosa Control AssoC 2005, 21:380-386.

73. Andreadis TG, Wolfe RJ: Evidence for reduction of native mosquitoes with increased expansion of invasive Ochlerotatus japonicus japonicus (Diptera: Culicidae) in the northeastern United States. J Med Entomol 2010, 47:43-52

74. Qualls WA, Mullen GR: Larval survey of tire-breeding mosquitoes in Alabama. J Am Mosq Control Assoc 2006, 22:601-608.

75. Miyagi I: Feeding habits of some Japanese mosquitoes on cold-blooded animals in the laboratory. Trop Med 1972, 14:203-217.

76. Williges E, Farajollahi A, Scott JJ, McCuiston LJ, Crans WJ, Gaugler R: Laboratory colonization of Aedes japonicus japonicus. J Am Mosa Control Assoc 2008, 24:591-593.

77. Takashima I, Rosen L: Horizontal and vertical transmission of Japanese encephalitis virus by Aedes japonicus (Diptera: Culicidae). J Med Entomol 1989, 26:454-458.

78. Sardelis MR, Dohm DJ, Pagac B, Andre RG, Turell MJ: Experimental transmission of eastern equine encephalitis virus by Ochlerotatus japonicus japonicus. J Med Entomol 2002, 39:480-484.

79. Sardelis MR, Turell MJ, Andre RG: Laboratory transmission of La Crosse virus by Ochlerotatus j. japonicus. J Med Entomol 2002, 39:635-639.

80. Sardelis MR, Turell MJ, Andre RG: Experimental transmission of St. Louis encephalitis virus by Ochlerotatus japonicus japonicus. J Am Mos Control Assoc 2003, 19:159-162.

81. Kamimura $K$ : The distribution and habit of medically important mosquitoes of Japan. Jpn J Sanit Zool 1968, 19:15-34 [In Japanese]. 
82. Apperson CS, Hassan HK, Harrison BA, Savage HM, Aspen SE, Farajollahi A, Crans W, Daniels TJ, Falco RC, Benedict M, Anderson M, McMillen L, Unnasch TR: Host feeding patterns of established and potential mosquito vectors of West Nile virus in the Eastern United States. Vector-Borne Zoon Dis 2004, 4:71-82.

83. Molaei G, Farajollahi A, Scott JJ, Gaugler R, Andreadis TG: Human bloodfeeding by the recently introduced mosquito, Aedes japonicus japonicus, and public health implications. J Am Mosa Control Assoc 2009, 25:210-214

84. Rochlin I, Gaugler R, Williges E, Farajollahi A: The rise of the invasives and decline of the natives: insights revealed from adult populations of container-inhabiting Aedes mosquitoes (Diptera: Culicidae) in temperate North America. Biol Invasions 2013, 15:991-1003.

85. Armistead JS, Nishimura N, Escher RL, Lounibos LP: Larval competition between Aedes japonicus and Aedes atropalpus (Diptera: Culicidae) in simulated rock pools. J Vector Ecol 2008, 33:238-246.

86. Lorenz AR: The Role of Algae in the Invasion Ecology the Mosquito Species Aedes japonicus japonicus (Diptera: Culicidae). East Lansing, MI: M.S. thesis, Michigan State University; 2012.

87. Alto BW: Interspecific larval competition between invasive Aedes japonicus and native Aedes triseriatus (Diptera: Culicidae) and adult longevity. J Med Entomol 2011, 48:232-242.

88. Hardstone MC, Andreadis TG: Weak larval competition between the invasive mosquito Aedes japonicus japonicus (Diptera: Culicidae) and three resident container-inhabiting mosquitoes in the laboratory. J Med Entomol 2012, 49:277-285.

89. Armistead JS, Arias JR, Nishimura N, Lounibos LP: Interspecific larval competition between Aedes albopictus and Aedes japonicus (Diptera: Culicidae) in northern Virginia. J Med Entomol 2008, 45:629-637.

90. Rai KS: Aedes albopictus in the Americas. Annu Rev Entomol 1991, 36:59-484.

91. Scholte EJ, Schaffner F: Waiting for the tiger: establishment and spread of the Aedes albopictus mosquito in Europe. In Emerging Pests and Vectorborne Diseases in Europe. Ecology and Control of Vectorborne Diseases, Volume 1. Edited by Takken W, Knols BGJ. Wageningen, The Netherlands: Wageningen Academic Publ; 2007:241-260.

92. Paupy C, Delatte $H$, Bagny L, Corbel V, Fontenille D: Aedes albopictus, an arbovirus vector: from the darkness to the light. Microbes Infect 2009, 11:1177-1185

93. Gratz NG: Critical review of the vector status of Aedes albopictus. Med Vet Entomol 2004, 18:215-227.

94. Bartlett-Healy K, Unlu I, Obenauer P, Hughes T, Healy S, Crepeau T, Farajollahi A, Kesavaraju B, Fonseca D, Schoeler G, Gaugler R, Strickman D: Larval mosquito habitat utilization and community dynamics of Aedes albopictus and Aedes japonicus (Diptera: Culicidae). J Med Entomol 2012, 49:813-824.

95. Turell MJ, O'Guinn ML, Dohm DJ, Jones JW: Vector competence of North American mosquitoes for West Nile virus. J Med Entomol 2001, 38:130-134.

96. Turell MJ, Sardelis MR, Dohm DJ, O'Guinn ML: Potential North American vectors of West Nile virus. Ann N Y Acad Sci 2001, 951:317-324.

97. CDC (Centers for Disease Control and Prveention): Mosquito species in which West Nile virus has been detected, United States, 1999-2012. http://www.cdc.gov/westnile/resources/pdfs/Mosquito\%20Species\%2019992012.pdf.

98. Mitamura T, Mori K, Kitaoka M, Tenjin S: Experiments on the transmission of the virus by various species of mosquitoes artificially infected with the virus of Japanese epidemic encephalitis. Tokyo lji Shinshi 1938, 62:812-819. Reports to the Ninth Meeting of the Committee on Encephalitis

99. Petrischeva PA, Shubladse AK: The vectors of autumn encephalitis in the maritime district. Arch Sci Biol (Moscow) 1940, 59:72-77 [In Russian]

100. Chagin KP, Kondratiev PI: Vectors of autumnal (Japanese) encephalitis in Primor'ye region and mesures for controlling them. Med Parazitol Parazit Bolezni 1943, 12:34-44 [In Russian].

101. Turell MJ, Byrd BD, Harrison BA: Potential for populations of Aedes $j$. japonicus to transmit Rift Valley fever virus in the USA. J Am Mosa Control Assoc 2013, 29:133-137.

102. Schaffner F, Vazeille M, Kaufmann C, Failloux A-B, Mathis A: Vector competence of Aedes japonicus for chikungunya and dengue viruses. Eur Mosq Bull 2011, 29:141-142.
103. Takashima I, Hashimoto N: Getah virus in several species of mosquitoes. Trans R Soc Trop Med Hyg 1985, 79:546-550.

104. Takashima I, Watanabe T, Ouchi N, Hashimoto N: Ecological studies of Japanese encephalitis virus in Hokkaido: interepidemic outbreaks of swine abortion and evidence for the virus to overwinter locally. Am J Trop Med Hyg 1988, 38:420-427.

105. Barrett ADT: Japanese encephalitis. In The Encyclopedia of ArthropodTransmitted Infections. Edited by Service MW. Wallingford, UK: CABI Publishing; 2001:239-246.

106. Rossi SL, Ross TM, Evans JD: West Nile virus. Clin Lab Med 2010, 30:47-65.

107. Beaty BJ: La Crosse virus. In The Encyclopedia of Arthropod-Transmitted Infections. Edited by Service MW. Wallingford, UK: CABI Publishing; 2001:261-265.

108. Weaver SC: Japanese encephalitis. In The Encyclopedia of Arthropod Transmitted Infections. Edited by Service MW. Wallingford, UK: CABI Publishing; 2001:151-159.

109. Kramer LD: St. Louis encephalitis. In The encyclopedia of arthropodtransmitted infections. Edited by Service MW. Wallingford, UK: CABI Publishing; 2001:448-454.

110. Balkhy HH, Memish ZA: Rift Valley Fever: an uninvited zoonosis in the Arabian peninsula. Int J Antimicrob Agents 2003, 21:153-157.

111. Gerdes GH: Rift Valley fever. Rev Sci Tech 2004, 23:613-623.

112. Chevalier V, Pépin M, Plée L, Lancelot R: Rift Valley fever - a threat for Europe? Euro Surveill 2010, 15:19506.

113. Hartley DM, Rinderknecht JL, Nipp TL, Clarke NP, Snowder GD, National Center for Foreign Animal and Zoonotic Disease Defense Advisory Group on Rift Valley Fever: Potential effects of Rift Valley fever in the United States. Emerg Infect Dis 2011, 17:e1.

114. Linthicum KJ, Davies FG, Kairo A, Bailey CL: Rift Valley fever virus (family Bunyaviridae, genus Phlebovirus). Isolations from Diptera collected during an inter-epizootic period in Kenya. J Hyg (Lond) 1985, 95:197-209.

115. Rezza G, Nicoletti L, Angelini R, Romi R, Finarelli AC, Panning M, Cordioli P, Fortuna C, Boros S, Magurano F, Silvi G, Angelini P, Dottori M, Ciufolini MG, Majori GC, Cassone A: Infection with Chikungunya virus in Italy: an outbreak in a temperate region. Lancet 2007, 370:1840-1847.

116. Sousa CA, Clairouin M, Seixas G, Viveiros B, Novo MT, Silva AC, Escoval MT, Economopoulou A: Ongoing outbreak of dengue type 1 in the Autonomous Region of Madeira, Portugal: preliminary report. Euro Surveill 2012, 17:20333.

117. Burt FJ, Rolph MS, Rulli NE, Mahalingam S, Heise MT: Chikungunya: a reemerging virus. Lancet 2012, 379:662-671.

118. Halstead SB: Dengue. Curr Opin Infect Dis 2002, 15:471-476.

119. Mair TS, Timoney PJ: Getah virus infection. In Infectious Disease of the Horse. Edited by Mair TS, Hutchinson RE. Ashford, Kent, UK: Geerings Print Ltd; 2009:155-158

doi:10.1186/1756-3305-7-59

Cite this article as: Kampen and Werner: Out of the bush: the Asian bush mosquito Aedes japonicus japonicus (Theobald, 1901) (Diptera, Culicidae) becomes invasive. Parasites \& Vectors 2014 7:59.

\section{Submit your next manuscript to BioMed Central and take full advantage of:}

- Convenient online submission

- Thorough peer review

- No space constraints or color figure charges

- Immediate publication on acceptance

- Inclusion in PubMed, CAS, Scopus and Google Scholar

- Research which is freely available for redistribution 